IFN Working Paper No. 925, 2012

\title{
Institution-Driven Comparative Advantage and Organizational Choice
}

Shon Ferguson and Sara Formai 


\title{
Institution-Driven Comparative Advantage and Organizational Choice*
}

\author{
Shon Ferguson ${ }^{\dagger}$ \\ Sara Formai $\ddagger$ \\ Research Institute \\ Bank of Italy \\ of Industrial Economics \\ First Version: April 2010 \\ This Version: September 2012
}

\begin{abstract}
The theory of the firm suggests that firms can respond to poor contract enforcement by vertically integrating their production process. The purpose of this paper is to examine whether firms' integration opportunities affect the way contract enforcement institutions determine international trade patterns. We find that the benefits of judicial quality for the exports of contract-intense goods are more muted in industries that have a greater propensity towards vertical integration arrangements with input suppliers. We show that our results are not driven by primitive industry characteristics. Our results confirm the role of judicial quality as source of comparative advantage and suggest that this depends not only on the technological characteristics of the goods produced but also on the way firms are able to organize the production process.
\end{abstract}

JEL Classification Codes: D23, F10, F14, L22, L23.

Keywords: International Trade, Comparative Advantage, Contract Enforcement, Vertical Integration.

*We thank Laura Alfaro, Gregory Corcos, Rikard Forslid, Jim Markusen, Philippe Martin, Thierry Mayer, Paul Segerstrom, Alexandre Skiba, Jonas Vlachos and the seminar participants at Stockholm University, the 2010 Nordic International Trade Seminars, ESWC 2010, the Bank of Italy and the 2012 IFN Stockholm Conference for their useful comments and suggestions. Financial support from the Jan Wallander and Tom Hedelius Foundation, the Marianne and Marcus Wallenberg Foundation and the Social Sciences and Humanities Research Council of Canada is gratefully acknowledged.

${ }^{\dagger}$ Corresponding author. Research Institute of Industrial Economics, Box 55665, 10215 Stockholm, Sweden. Tel: +4686654500 Fax: +4686654599 Email: shon.ferguson@ifn.se

${ }^{\ddagger}$ Email: sara.formai@esterni.bancaditalia.it 


\section{Introduction}

A substantial body of empirical work has established that the quality of a country's institutions has a profound effect on its economic performance. Several influential works have studied and explored the idea that legal, financial and other types of institutions are indeed "inputs" to the production process and give a nation a comparative advantage in industries relatively intensive in the use of the services provided by these institutions. These papers show that judicial quality (Nunn 2007, Levchenko 2007), financial development (Svaleryd and Vlachos 2005, Manova 2008) and labor market flexibility (Cuñat and Melitz 2009) contribute to a country's comparative advantage in the same way as more traditional sources such as factor endowments and technology. ${ }^{1}$

One important matter that these empirical contributions do not account for, however, is that firms' organizational form may help them to cope with the limitations of the institutional environment. Namely, firms that are more vertically integrated with input suppliers will be less reliant on the external contracting environment to alleviate hold-up problems. We thus test the hypothesis that vertical integration is a substitute for well-functioning contract enforcement institutions when producing contract-intense goods. Accounting for organizational form allows us to better understand the effect of judicial quality on the composition of exports.

In this paper, we investigate the effect of judicial quality on comparative advantage across industries that vary in their contract intensity and their propensity to vertically integrate with input suppliers. A contract-intense good is defined as a good whose production process is intensive in the use of highly specialized and customized inputs. We measure industry contract-intensity using Nunn's (2007) measure of contract intensity. The trade of contract-intense goods has grown substantially over the past three decades, making its study all the more relevant for the modern economy.

The main methodological contribution of this paper is that we use a new measure of industry-level "vertical integration propensity" based on observed vertical integration outcomes from U.S. firm-level data. This measure has the advantage that it is a direct measure of vertical integration based mainly on sector characteristics. In contrast, previous literature has used proxy measures such as the number-of-inputs or industry value-added.

\footnotetext{
${ }^{1}$ See also Chor (2010) for a quantification of the importance of various sources of comparative advantage.
} 
Our analysis extends the work of Nunn (2007) and Levchenko (2007), who show that countries with better legal systems export relatively more of "complex goods" that are contract-intense and thus more sensitive to poor contract enforcement. ${ }^{2}$ We test if this effect is diminished for industries that also have a high propensity to vertically integrate with their input providers. This should hold if firms are vertically integrating around the problem of contract incompleteness resulting from poor judicial quality. The analysis thus tests the role of incomplete contract theory in explaining trade flows.

Our results show that the sensitivity of contract-intense industries' exports to judicial quality is affected significantly by how vertically integrated the industry is with its suppliers. In other words, the exports of contract-intense industries that are also highly vertically integrated are not sensitive at all to judicial quality, whereas the exports of contract-intense industries that exhibit low degrees of vertical integration are highly sensitive to judicial quality. Our results are robust to several control variables and are not driven by primitive industry characteristics such as capital intensity or skill intensity. In our specifications we also control for other potential sources of comparative advantage, such as factor endowments and the possibility that countries specialize in different goods according to their level of development.

The paper is organized as follows. The theoretical background is described in section 2. Variable descriptions and data sources are discussed in section 3. The empirical specification and main results are explained in sections 4 and 5 respectively. The details of several robustness checks are explained in section 6 . Conclusions follow in section 7 .

\section{Theoretical Background}

The idea that countries with better judicial quality have a comparative advantage in contract-intense goods finds theoretical support in the incomplete contract literature. The argument, pioneered by Williamson (1979) and further developed by Grossman and Hart (1986), is the following: when contracts are not fully enforceable ex post, the contracting parties tend to under-invest ex ante and this problem, the "hold-up problem", is bigger the more the investment is relationship-specific. Consider the case of an upstream firm (U) and a downstream firm (D) that transact a customized intermediate good. U's investments in customization and D's effort

\footnotetext{
${ }^{2}$ See Levchenko (2007) and Acemoglu et al. (2007) for a theoretical analysis.
} 
in adapting its production process to use that specific input are both relationshipspecific because their value is higher within this buyer-seller relationship than outside it. If the contract is not enforced and the trade agreement falls apart then $\mathrm{U}$ is left with a good that has a lower value for any other buyer, while D will find it difficult to procure a good substitute from another supplier. Given such a risk both parties in the transaction will under-invest in the relationship and the production of the final good will be inefficient. The better contract enforcement institutions are the higher the probability for the contract to be enforced and the lower the efficiency loss due to underinvestment. The resulting cost advantage will be greater the more important relation-specific inputs are in the production of the final good. From this it follows that countries with better legal institutions have a comparative advantage in the production of those goods intensive in relationship-specific inputs where contract enforcement is important. Although this hypothesis has found strong empirical support, it takes into account only part of the theoretical predictions. The hold-up problem entails a transaction cost associated with market exchanges and, as Coase (1937) suggested, the transaction cost may be avoided or reduced by choosing the optimal organizational structure. This idea is fully developed by Williamson $(1971,1979)$ who suggested vertical integration as an organizational response to the hold-up problem. Williamson posits that moving the transactions of the specific inputs inside the firm's boundaries should alleviate the dependence on contract enforceability. If this is true then judicial quality should have a muted effect in driving comparative advantage of contract-intense goods when the firms producing them are more vertically integrated. This is the hypothesis that we test.

Our analysis focuses on testing Williamson's transaction cost theory and abstracts from alternative theories of organization such as the Property Rights Theory (PRT) developed by Grossman and Hart (1986) and Hart and Moore (1990). ${ }^{3}$ The PRT approach emphasizes that backward vertical integration may not lead to a more efficient outcome since it erodes the suppliers incentives to invest in the relationship. As a consequence, according to the PRT it is not entirely clear whether relationship-specific investments should induce more or less backward vertical integration. ${ }^{4} 5$

\footnotetext{
${ }^{3}$ See Gibbons (2005) for a comparison of the two theories.

${ }^{4}$ As noted by Lafontaine and Slade (2007), Williamson's transaction costs approach to vertical integration, perhaps because of its more testable predictions, has stimulated much more empirical work and has found considerable support in the data.

${ }^{5}$ In addition, we do not consider the Antràs et al. (2009) hypothesis that multinational firms are more reliant on within-firm technology deployment in countries with poor investor protection.
} 


\section{The Data}

To examine the effect of judicial quality on comparative advantage we combine data on countries' characteristics, industries' characteristics and countries' exports by industry. We employ a cross section analysis, mainly based on the data set from Nunn (2007), which uses observations for 1997. This section illustrates the sources and the definitions of our main variables and controls. ${ }^{6}$

\subsection{Contract Intensity}

According to the theoretical framework we have in mind, the sensitivity of a given industry to the quality of contract enforcement institutions is an exogenous industry characteristic and it derives from the relative importance in the production process of those inputs that, due to some specificity, suffer from hold-up problems. A direct measure of such a variable does not exist and we use the proxy constructed and employed by Nunn (2007). As an indicator of whether or not an input requires relation-specific investments he considers Rauch's (1999) commodity classification. This consists of three groups: goods traded on organized exchanges, goods not traded on organized exchanges but nevertheless possessing a reference price in trade publications, and all other goods. Nunn defines an input as being relationshipspecific if it is neither purchased on an organized exchange nor reference-priced. Using this information, together with information from the U.S. Bureau of Economic Analysis (BEA) Input-Output (I-O) Table on input use, Nunn constructs for each final good the following measures of the proportion of its intermediate inputs that are relationship-specific:

$$
z_{i}=\sum_{j} \theta_{i j} R_{j}^{\text {neither }}
$$

where $\theta_{i j}$ is the weight of input $j$ in the production of the final good $i$ and $R_{j}^{\text {neither }}$ is the proportion of input $\mathrm{j}$ that is neither sold on an organized exchange nor reference priced. $^{7}$

Although there are several alternative measures of contract intensity in the literature, we choose this measure because it most clearly captures the problem of asset specificity with upstream suppliers. Levchenko (2007), for example, uses the

\footnotetext{
${ }^{6}$ Descriptive statistics for the main variables are presented in an online appendix.

${ }^{7}$ Rauch's original classification groups goods into 1,189 industries according to the 4-digit SITC Rev.2 Classification. These data are aggregated into 342 industries following the BEA's I-O industry classification. This explains why $R_{j}^{\text {neither }}$ is a proportion and not simply a $0 / 1$. We refer to Nunn (2007) for a detailed description of the indicator and its construction.
} 
Herfindahl index of intermediate input use as an inverse measure of product contractintensity. The motivation for using the Herfindahl index is that the more suppliers a firm has and the less they are concentrated, the more the firm depends on good contract enforcement because it has to deal with a higher number of equally important contracts. Costinot (2009) instead bases its measure of contract-intensity on survey data on the length of time needed to become fully trained and qualified in a given industry. Berkowitz et al. (2006) and Ranjan and Lee (2007) also use the data from Rauch (1999) but they do so to classify the downstream industries according to their own good's contract-intensity, without looking at the type of intermediate inputs employed.

The correlation of the contract intensity measure $\left(z_{i}\right)$ with other industry variables is reported in Table 1. Contract intensity is positively correlated with human capital intensity and, more surprisingly, negatively correlated with physical capital intensity.

\subsection{Vertical Integration Propensity}

Our measure of industries' propensity to vertically integrate is taken from Acemoglu et al. (2009), which captures the extent of vertical integration of an industry with its input suppliers. They study the institutional determinants of vertical integration and in doing so they use a large and detailed firm level data set from Dun \& Bradstreet's WorldBase database. WorldBase contains information on the primary industry in which each firm operates, as well as up to five secondary industries. Combining information on firms' primary and secondary industry classifications with the U.S. I-O Table, the authors compute for each firm in the sample the dollar value of inputs from industries in which the firm operates that is required to produce one dollar's worth of the firm's primary output. They then create a similar index also for secondary industries in which a firm is active. Each firm's vertical integration index is then defined as the average of these indices.

Stated formally, the vertical integration index of firm $f$ from country $c$, is then given by:

$$
v_{c f}=\frac{1}{\left|N_{f}\right|} \sum_{i \in N_{f}} \sum_{j \in N_{f}} V I_{j i}
$$

where $N_{f}$ is the set of industries in which the firm is active, $\left|N_{f}\right|$ denotes the number of these industries and $V I_{j i}$ the entry of the I-O table representing the dollar value of inputs from sector $j$ in producing one dollar of output in sector $i$. The index is 
the average among the $\left|N_{f}\right|$ sectors of activity of the input requirements produced in-house.

The authors convert the firm-level measures of vertical integration to an industrylevel measure by the following method: using data for U.S. firms only (i.e. $c=U S A$ ), they regress their firm-level vertical integration index on a set of industry dummies:

$$
v_{U S A f}=d_{i}+\epsilon_{f}
$$

where the $d_{i}$ s are 76 industry dummies at the 1992 I-O 2-digit level of aggregation. In particular, $d_{i}=1$ if firm $f$ 's primary activity is in industry $i$. The resulting point estimates for each industry dummy represent the average level of vertical integration in each industry with its input suppliers. We match the dummy coefficients based on the BEA's 1992 I-O classification from Acemoglu et al. (2009) with the rest of our data that uses the BEA's 1997 I-O classification using the concordances 1992 I-O - SIC87 - HS10 - 1997 I-O. Vertical integration data for 491992 I-O industries enter the regressions for which there is corresponding data on exports and other industry-specific variables. ${ }^{8}$

To the best of our knowledge there is no variable in the literature that has extensively served as a measure of industry-level vertical integration propensity. Nunn and Trefler $(2008,2011)$ measure cross-border vertical integration using U.S. data on the share of multinational imports that are intra-firm. Carluccio and Fally (2012) use a similar measure for multinational firms with operations in France. Nunn (2007) uses the number of inputs employed in the production process as a measure of the difficulty of vertical integration. The idea behind his choice is the following: if there are fixed costs in producing each single input, the total cost to integrate the entire production chain in-house is increasing in the number of inputs required.

A rich set of theories has been developed to explain what drives vertical integration decisions. Industrial organization theories have tended to focus on vertical integration as a response to pre-existing market power or as a strategic action to create market power in upstream or downstream markets. For instance, vertical integration can arise to reduce double marginalization issues (Bain 1956, 1959), to foreclose product-market competition by raising rival's costs (Ordover, Saloner and Salop 1990) or to bypass contract incompleteness to restore upstream market power (Hart and Tirole 1990). Other reasons include efficiency seeking explanations. Ex-

\footnotetext{
${ }^{8}$ Vertical integration data for 581992 I-O industries match successfully with our existing data and have positive export values. We are left with 491992 I-O industries due to a lack of corresponding factor intensity data for some sectors.
} 
amples are given by "supply security" reasons in case of demand uncertainty (see Carlton (1979)) and life cycle arguments, when for an infant industry the initial demand of specialized inputs is too small to support independent suppliers (Stigler 1951). While not excluding these rationales, organizational economics based theories of vertical integration stress the importance of contract imperfections and transaction costs as necessary conditions for vertical integration to arise (See Joskow (2005) and Lafontaine and Slade (2007) for detailed surveys of the literature). Our index of vertical integration, as based on actual integration outcomes, can thus be affected by all the above mentioned factors and allows us to maintain an agnostic perspective about the dominant forces.

The use of U.S. firm level data only for the computation of the vertical integration measure has some advantages. First, as the U.S. is characterized by slack institutional constraints, the ranking provided by this measure is mainly driven by industry-specific characteristics, as opposed to country-specific characteristics, making it a good proxy for vertical integration propensity in other countries. Second, as the measure is not country specific, we can abstract from endogeneity issues. ${ }^{9}$ Third, the U.S. is the country with the most firms in the WorldBase database, allowing for precise estimation of $d_{i}$ across all industries. To summarize, the index from Acemoglu et al. (2009) is meant to capture the natural propensity of an industry to integrate based on sector characteristics, holding the institutional and policy environment constant, and is not meant to be interpreted as representing actual outcomes in all countries in the sample. ${ }^{10}$

One concern is that vertical integration may be determined in part by other underlying industry variables that interact with judicial quality. We address this by controlling for capital intensity, skill intensity, labor intensity other industryspecific variables in our regression analysis. The correlations between our vertical integration propensity measure $\left(v i_{i}\right)$ and some of these variables are reported in Table 1. Vertical integration propensity is positively correlated with physical capital intensity and negatively correlated with skill intensity. It is interesting to note that the correlation coefficient between vertical integration propensity and Nunn's number-of-inputs variable is very low (0.13) and not statistically significant at the 1 percent level.

\footnotetext{
${ }^{9}$ Although we cannot exclude the possibility that the pattern of specialization in U.S. production and exports affects the extent of vertical integration in U.S. industries, we cannot think of a theory or a reason why this would be the case.

${ }^{10}$ Papers that treat vertical integration as an outcome variable include Antràs (2003, 2005), Nunn and Trefler (2008, 2011), Acemoglu et al (2009) and Alfaro et al (2011).
} 


\subsection{Trade Flows, Judicial Quality, and Controls}

Industry-level data on trade flows are from Feenstra et al. (2005). The data is converted from the 4-digit SITC Rev.2 code to the BEA 1997 I-O industry classification. Only non-zero trade flows are included in the regression. Similarly, judicial quality is measured by the "Rule of Law" from Kaufmann et al. (2008), using the measure from 1998. This variable measures for each country the extent to which agents have confidence in the judiciary system and in law enforcement. We employ a wide variety of country-level and industry-level control variables, including stocks of physical and human capital, factor intensities, GDP per capita and financial development. The origin and construction of these variables is described in Appendix A.

Table 2 shows that the "Rule of Law" measure is positively correlated with countries' skill and capital endowments, GDP per capita and financial development. This highlights the importance of controlling for these country-specific variables in our analysis.

\section{Empirical Specification}

The goal of cross-section analysis is to exploit the variation in judicial quality across countries. This is particularly useful for the case of judicial quality since there is very little time variation in the Rule of Law index.

We test our hypothesis by estimating the following equation:

$$
T_{c i}=\beta_{0}+\beta_{1}\left(z_{i} Q_{c} v i_{i}\right)+\beta_{2}\left(z_{i} Q_{c}\right)+\beta_{3}\left(Q_{c} v i_{i}\right)+\mathbf{X}_{c i}+\alpha_{c}+\alpha_{i}+\varepsilon_{c i} .
$$

$T_{c i}$ is the $\log$ value of country c's exports to the rest of the world in industry $i$. $Q_{c}$ is judicial quality, proxied by the "Rule of Law" index from Kaufmann et al. (2008). $z_{i}$ is Nunn's (2007) industry-specific measure of contract intensity, while $v i_{i}$ is Acemoglu et al.'s (2009) measure of vertical integration propensity. $\mathbf{X}_{c i}$ is a vector of country-industry interaction controls, while $\alpha_{c}$ and $\alpha_{i}$ denote country fixed effects and industry fixed effects respectively. In this equation exports are explained by interactions of an industry characteristic with a country characteristic. This specification was first used by Rajan and Zingales (1998) to test whether industries that are more dependent on external financing grow faster in countries with better developed financial markets.

Note that this specification measures the effect of country characteristics and 
industry characteristics on the composition of trade, not the total volume of trade. The effect of country characteristics such as institutional quality $Q_{c}$ on the volume of trade is captured here by the country fixed effects. This formulation is thus conceptually distinct from studies such as Anderson and Marcouiller (2002) that use a gravity model to measure the effect of institutional quality on the total volume of trade in all sectors of an economy.

Nunn's (2007) hypothesis was that countries with better contract enforcement have a comparative advantage in producing final goods that use intensively inputs requiring relationship-specific investments. This is indicated by a positive coefficient for $\beta_{2}$, and means that countries with better contract enforcements will specialize in contract-intensive industries.

Our analysis focuses on the triple-interaction $z_{i} Q_{c} v i_{i}$ in equation (1), since we are interested in how sensitivity of contract-intense industry exports to judicial quality depends on industries' propensity to vertically integrate. A negative coefficient for $\beta_{1}$ implies that the effect of contract enforcement on comparative advantage in contract-intensive industries is diminished when the industry is more vertically integrated. Vertically integrating around the problem of contract incompleteness thus reduces the necessity of good judicial institutions for exporting contract-intense goods. Other interaction terms are also included, such as $Q_{c} v i_{i}$. These control interactions are not the focus of the analysis but we report them in all regressions nonetheless. Additional control variables include the typical sources of comparative advantage such as physical capital and human capital. We de-mean the raw variables for contract intensity, vertical integration propensity, capital intensity and skill intensity prior to the regression analysis in order to ease the interpretation of the regression coefficients. All industry-specific variables in the analysis are taken from U.S. data. Identification thus requires that the ranking of sectors in terms of contract intensity, vertical integration propensity, and other industry-specific controls remains relatively stable across countries.

\section{Main Results}

The results are presented in Tables 3 and 4. We estimate equation (1) using data on at most 70 countries and 164 industries in the year $1997 .{ }^{11}$ Using Nunn's data

\footnotetext{
${ }^{11}$ Factor endowment data are only available for 70 countries, and we also lose observations on Tanzania in regressions where we include our financial development control. Nonetheless, the sample includes countries with a wide range of judicial quality (see descriptive statistics in the
} 
allows us to directly compare our results with his original results. Standard errors are clustered at the 1992 I-O 2-digit industry level in all specifications. ${ }^{12}$

Table 3 provides the baseline results. We observe that the coefficient for the triple interaction, $z_{i} Q_{c} v i_{i}$, is negative and statistically significant across all specifications. These results support our hypothesis that judicial quality is less important for comparative advantage within industries for which vertical integration is prevalent. We report standardized beta coefficients in columns (1) - (3), which allows us to directly compare the relative size of the coefficients across different variables. The vertical integration (VI)-judicial quality triple interaction has a large coefficient across all columns of Table 3, with a one standard deviation increase in vertical integration propensity reducing the effect of the judicial quality interaction by between .11 and .15 standard deviations.

We find that the coefficient for judicial quality interaction, $z_{i} Q_{c}$, is positive and statistically significant across all columns of Table 3 . Since all other industry-level variables in Table 3 have a mean of zero we can interpret this coefficient as the effect of judicial quality on exports of contract-intense goods for an industry with an average level of vertical integration propensity, capital intensity and skill intensity. We also find that $Q_{c} v i_{i}$ is negative and statistically significant in columns (1) and (3), suggesting that exports in vertically integrated sectors in general respond less favorably to judicial quality.

We control for traditional sources of comparative advantage in columns (1) and (2) of Table 3. The controls in column (1) are necessary in order to reassure that the $v i_{i}$ index is not simply proxying for more primitive industry characteristics. The controls added in column (2) assure that the Rule of Law index is not proxying for capital or skill endowments. It turns out that our VI-judicial quality triple interaction is robust to the inclusion of these controls.

We control for financial development as a source of comparative advantage in column (3) of Table 3. Acemoglu et al. (2009) argue and show that a stronger financial development is a prerequisite for firms to efficiently integrate in response to high contracting costs. Vertical integration, either if achieved via the acquisition

online appendix.) Factor intensity data are only available for 182 manufacturing industries. We lose an additional 18 industries due to a poor match with our vertical integration propensity variable. Missing observations and zero observations also lead to a smaller sample size. We do not include export zeros in the regressions since they comprise only 14 percent of the trade flow observations. The results in Table 3 represent 69 percent of world trade in manufacturing goods according to Feenstra's (2005) world trade data.

${ }^{12}$ Clustering at the 1992 I-O 2-digit industry level yields the most conservative standard errors compared to other alternatives. 
of an existing supplier or through the establishment of a new production plant, is a costly option and may require access to external finance. ${ }^{13}$ If this argument is correct then vertically integrated and contract-intense industries will respond most favorably to improved financial development. Including the financial development controls also rules out the concern that correlation between countries' judicial quality and financial development may be driving or results. The results indicate that while financial development is indeed an important source of comparative advantage for vertically integrated and contract-intense industries our main results remain statistically significant.

Column (4) reports the regular, non-beta coefficients that correspond to the regression in column (3). The regular coefficients are used in throughout the rest of this section to quantify the impacts of vertical integration propensity. We first examine the two parts of the estimating equation that are of most interest, $\left(\beta_{1} v i_{i}+\beta_{2}\right) z_{i} Q_{c}$. We can use the term in brackets to illustrate the differential impact of judicial quality on exports in contract intensive industries for differing levels of vertical integration propensity. For an industry with a vertical integration propensity at the 75 th percentile $\left(v i_{i}=0.50\right)$, the overall impact is $(-0.846 \times 0.50)+2.518=2.09$, while for an industry with a vertical integration propensity at the 25 th percentile $\left(v i_{i}=-2.53\right)$, the overall impact is $(-0.846 \times-2.53)+2.518=4.66$, more than twice the size. The estimated impact of judicial quality on exports of contract-intense goods thus critically depends on industries' propensity to vertically integrate. ${ }^{14}$

The effect of vertical integration on the response of contract-intense goods to institutional quality is economically significant. Take the hypothetical case of a country improving its judicial quality from the 50th percentile of the Rule of Law country ranking to the 60th percentile. The point estimates in column (4) of Table 3 indicate that contract-intense goods exports (75th percentile of the contractintensity ranking) would rise nine percentage points more in the country's low-VI industries than in its high-VI industries (comparing the 25th vs. 75 th percentile of the VI ranking).

We complement our regression results with a graphical analysis of how the marginal effects of judicial quality on trade vary with industry characteristics. Derivation of (1) illustrates that these marginal effects are a function of industry-level

\footnotetext{
${ }^{13}$ See also McMillan and Woodruff (1999) for evidence on firms in Vietnam.

${ }^{14}\left(\beta_{1} v i_{i}+\beta_{2}\right)$ is illustrated graphically for all the possible values of the $v i_{i}$ variable in the online appendix.
} 
contract intensity, vertical integration propensity, and factor intensities:

$$
\frac{\partial T_{c i}}{\partial Q_{c}}=\beta_{1} z_{i} v i_{i}+\beta_{2} z_{i}+\beta_{3} v i_{i}+\beta_{4} z_{i} k_{i}+\beta_{5} k_{i}+\beta_{6} z_{i} h_{i}+\beta_{7} h_{i},
$$

where $k_{i}$ and $h_{i}$ are industry-level capital and skill intensity respectively. We cannot capture the true marginal effects because some of the effects of institutions are absorbed by the country dummies. This is not a problem though since we are interested in knowing how the marginal effects differ across industries that vary in contract intensity and vertical integration propensity. The connection between these these industry characteristics and the marginal effects is illustrated in figure 1. Panel A of figure 1 shows the marginal effect of judicial quality is unrelated to contract intensity for industries with vertical integration propensity above the median. However, panel B of figure 1 shows a clear positive relationship between the marginal effect of judicial quality and industry contract intensity for industries with below-median vertical integration propensity.

\section{Robustness}

Additional control variables are added to the baseline specification in Table 4 . The full set of controls used in Table 3 is always included, but not reported. We add controls for other determinants of trade flows in column (1) of Table 4. Log income per capita is interacted with industry measures for share of value-added in shipment, intra-industry trade and TFP growth in the previous twenty years. These interactions control for the possibility that, for reasons unrelated to contract enforcement, high-income countries have a comparative advantage in high value-added industries, industries with a high degree of fragmentation of the production process or a rapid rate of technological progress. ${ }^{15}$ We also include an interaction of log income with one minus the Herfindahl index of input concentration. Clague (1991a,b) argues that the Herfindahl index measures how "self contained" an industry is, and that less developed countries tend to specialize in industries that are relatively more "self contained". This interaction thus controls for the possibility that high-income countries will specialize in industries that are less "self contained". The results across all columns of Table 4 indicate that the interaction of log income with the intra-industry trade measure is the most signficant of these controls.

\footnotetext{
${ }^{15}$ We refer to the reader to Nunn (2007) for a detailed description of these industry-level control variables.
} 
Two additional control interactions are included in column (1). The first controls for the importance of financial development in capital-intense industries, $k_{i} C R_{c}$. The second controls the importance of financial development in industries with faster technological growth, $t f p_{i} C R_{c}$. The inclusion of these controls is motivated by previous studies on financial development and export composition and the possibility that our results are driven by credit constraints along these industry dimensions. Both of these controls are statistically significant with the expected sign. Nonetheless, our triple interactions are robust to these controls.

In Column (2) of Table 4 we add further control variables to check whether the Rule of Law index is simply proxying for GDP per capita and if the interaction of $z_{i}$ and $v i_{i}$ with GDP per capita is driving our results. This turns out not to be the case, as our significant result for $z_{i} Q_{c} v i_{i}$ persists. Finally, column (3) of Table 4 includes a triple interaction of judicial quality with labor intensity. This control interaction checks whether our measure of vertical integration is proxying for industries that are labor-intense. While the triple control interaction $z_{i} Q_{c} w_{i}$ is significant with a negative sign, our main result continues to be statistically significant. Overall, our significant and economically meaningful results for the triple interaction $z_{i} Q_{c} v i_{i}$ are robust to a wide array of controls and are not driven by underlying industry characteristics. ${ }^{16}$

The stability of the available proxies of countries' judicial quality over time lends support to our claim that judicial quality is not influenced by exports in sectors sensitive to the external contracting environment. Nonetheless, one may argue that countries that already export contract-intense goods in sectors where vertical integration is not possible have an extra incentive to improve their contract enforcement institutions. Reverse causality of this kind would only arise, however, if poor contract enforcement instutions were impeding comparative advantage in those sectors in the first place. In other words, the existance of this kind of reverse causality would be consistent with the idea that poor contract enforcement reduces comparative advantage in sectors that are both contract-intense and have a low vertical integration propensity. We thus argue that our findings indicate a hold-up problem

\footnotetext{
${ }^{16}$ The results are robust to controlling for non-linear effects of contract intensity by including $z_{i}^{2} Q_{c}$ as a regressor. The results are also robust to including a judicial quality triple interaction based on Herfindahl index of input concentration, $-h f_{i} Q_{c} v i_{i}$. As a final robustness check we run the baseline regressions using data on industry output at the country level from the UNIDO INDSTAT4 dataset as our dependent variable. Our triple interaction coefficient of interest is robust to this alternative regression strategy. This provides additional evidence that our results using export data capture the pattern of production specialization. These results are available in the online appendix.
} 
channel running from judicial quality to exports. ${ }^{17}$

\section{Conclusion}

The purpose of this paper was to show that organizational form matters when measuring the effect of judicial quality on comparative advantage. We argue that firms can circumvent the hold-up problem by vertically integrating with suppliers. These effects will be most pronounced in contract-intense industries that are most susceptible to the hold-up problem. We tested this hypothesis using data for several countries that differ in institutional quality and several industries that differ in their contract-intensity and propensity to vertically integrate.

Overall, we find that a country's exports of contract-intense goods are less sensitive to judicial quality for sectors that also have a natural inclination to vertically integrate. We interpret this as evidence that vertical integration is a substitute for reliance on the external contracting environment to aleviate hold-up problems. The results are robust to a wide variety of controls. Moreover, our results suggests that the influence of vertical integration is independent of underlying industry characteristics such as physical capital intensity or skill intensity.

These results can help us to understand how economies respond to improvements in the institutions that govern contract enforcement. In particular, we predict that countries with a more vertically integrated industrial compostion will respond less elastically to improvements in judicial quality. Organizational attributes may also play a role in determining the economic impact of other types of institutions as well, which we see as a promising direction for future research.

\footnotetext{
${ }^{17}$ We do not pursue an instrumental variables approach to control for reverse causality because of the difficulty in finding an instrument that satisfies the exclusion restriction. The lack of good instruments is a common limitation in studies that measure the economic effect of institutions.
} 
Figure 1: Marginal effect of judicial quality on exports

Panel A: Marginal effect of judicial quality on exports for industries with vertical integration propensity above the median

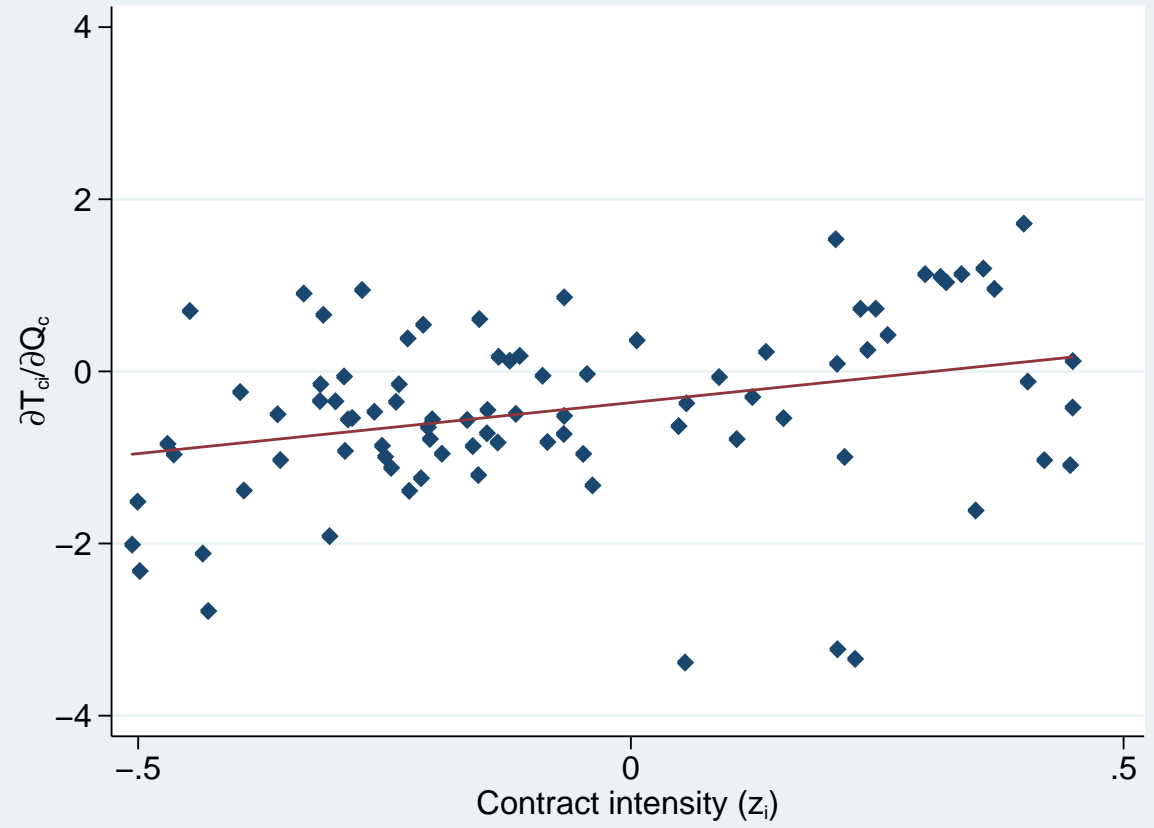

Panel B: Marginal effect of judicial quality on exports for industries with vertical integration propensity below the median

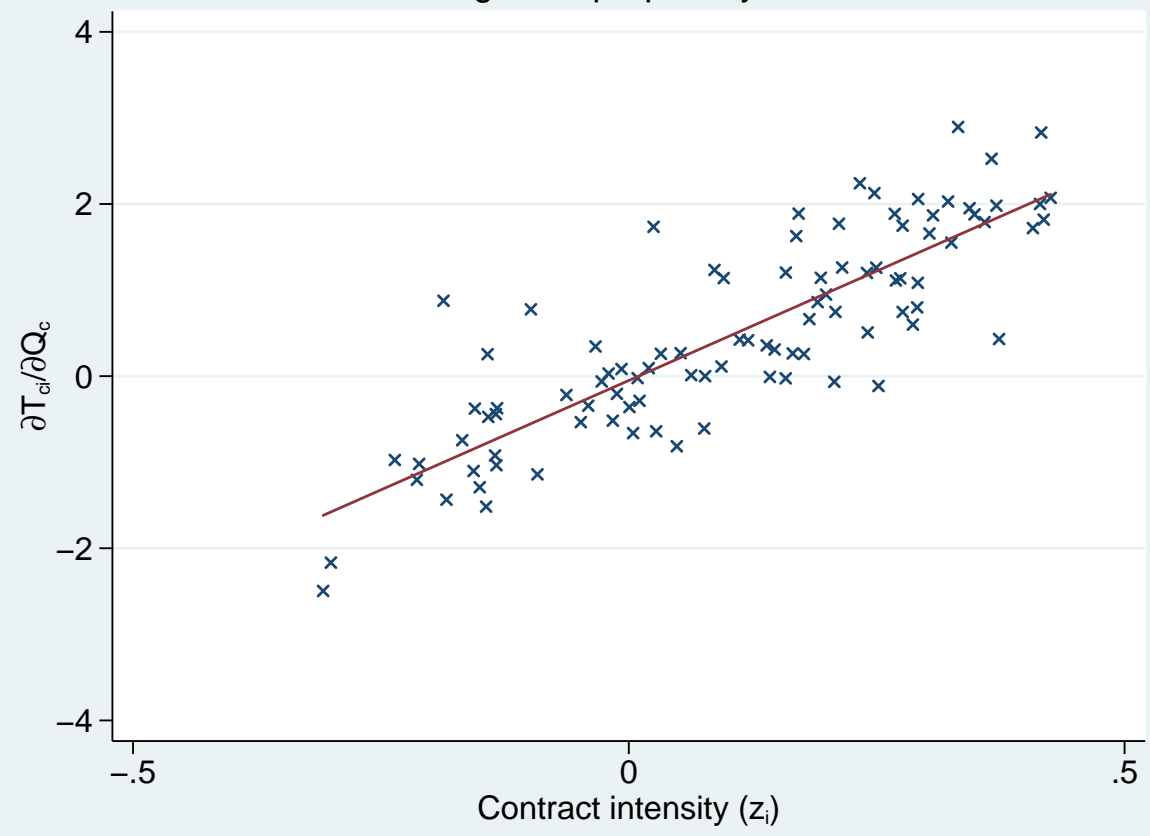

Notes: Marginal effects derived from the regression provided in column (4) of Table 3. Each dot represents a 6-digit 1997 I-O industry. A line of best fit is also provided in each panel. 
Table 1: Correlations of Industry-Level Variables

\begin{tabular}{lcccccc}
\hline \hline & & & & & & \\
& $z_{i}$ & $v i_{i}$ & $h_{i}$ & $k_{i}$ & $w_{i}$ & $I_{i}^{n_{i}>\bar{n}}$ \\
\hline & & & & & & \\
Contract-intensity: $z_{i}$ & 1.00 & & & & & \\
Vertical integration propensity: $v i_{i}$ & $-0.36^{*}$ & 1.00 & & & & \\
Skill intensity: $h_{i}$ & $0.45^{*}$ & -0.10 & 1.00 & & & \\
Capital intensity: $k_{i}$ & $-0.49^{*}$ & $0.33^{*}$ & $-0.24^{*}$ & 1.00 & & \\
Labor intensity: $w_{i}$ & $0.33^{*}$ & -0.12 & -0.05 & -0.16 & 1.00 & \\
Number of inputs dummy: $I_{i}^{n_{i}>\bar{n}}$ & 0.14 & 0.13 & $0.24^{*}$ & 0.02 & -0.02 & 1.00 \\
& & & & & & \\
\hline
\end{tabular}

Notes: " $I_{i}^{n_{i}>\bar{n}}$ " is the inverse measure of vertical integration used by Nunn (2007). Correlation coefficients are reported for the 1641997 I-O industries included in the regression in Table 3, column (3). * indicates significance at the 1 percent level.

Table 2: Correlations of Country-Level Variables

\begin{tabular}{lccccc}
\hline \hline & $Q_{c}$ & $H_{c}$ & $K_{c}$ & $Y_{c}$ & $C R_{c}$ \\
\hline & & & & & \\
Rule of Law: $Q_{c}$ & 1.00 & & & & \\
Human capital: $H_{c}$ & $0.69^{*}$ & 1.00 & & & \\
Physical capital: $K_{c}$ & $0.74^{*}$ & $0.82^{*}$ & 1.00 & & \\
GDP per capita: $Y_{c}$ & $0.86^{*}$ & $0.81^{*}$ & $0.91^{*}$ & 1.00 & \\
Credit/GDP ratio: $C R_{c}$ & $0.73^{*}$ & $0.59^{*}$ & $0.66^{*}$ & $0.73^{*}$ & 1.00 \\
& & & & & \\
\hline \hline & & & & & \\
Notes: Correlation coefficients are reported for the 69 countries included in the \\
regression in Table 3, column (3). ${ }^{*}$ indicates significance at the 1 percent level.
\end{tabular}


Table 3: Vertical Integration and the Determinants of Comparative Advantage

\begin{tabular}{|c|c|c|c|c|}
\hline & \multicolumn{3}{|c|}{ Beta coefficients and standard errors } & \multirow{2}{*}{$\begin{array}{c}\text { Raw coefs. } \\
(4)\end{array}$} \\
\hline & (1) & $(2)$ & (3) & \\
\hline VI-judicial quality triple interaction: $z_{i} Q_{c} v i_{i}$ & $\begin{array}{c}-0.107 \\
(0.036)^{* * *}\end{array}$ & $\begin{array}{c}-0.115 \\
(0.036) * * *\end{array}$ & $\begin{array}{c}-0.146 \\
(0.043)^{* * *}\end{array}$ & -0.846 \\
\hline Judicial quality interaction: $z_{i} Q_{c}$ & $\begin{array}{c}0.322 \\
(0.052)^{* * *}\end{array}$ & $\begin{array}{c}0.217 \\
(0.038)^{* * *}\end{array}$ & $\begin{array}{c}0.122 \\
(0.046)^{* *}\end{array}$ & 2.518 \\
\hline Judicial quality $\times$ VI: $Q_{c} v i_{i}$ & $\begin{array}{c}-0.068 \\
(0.033)^{* *}\end{array}$ & $\begin{array}{l}-0.025 \\
(0.029)\end{array}$ & $\begin{array}{c}-0.097 \\
(0.035)^{* * *}\end{array}$ & -0.145 \\
\hline Skill interaction: $h_{i} \ln \left(H_{c}\right)$ & $\begin{array}{c}0.008 \\
(0.018)\end{array}$ & $\begin{array}{l}-0.002 \\
(0.027)\end{array}$ & $\begin{array}{l}-0.001 \\
(0.025)\end{array}$ & -0.020 \\
\hline Capital interaction: $k_{i} \ln \left(K_{c}\right)$ & $\begin{array}{l}-0.021 \\
(0.047)\end{array}$ & $\begin{array}{c}0.094 \\
(0.060)\end{array}$ & $\begin{array}{c}0.105 \\
(0.065)\end{array}$ & 0.159 \\
\hline \multicolumn{5}{|l|}{ Additional factor intensity controls: } \\
\hline$z_{i} Q_{c} k_{i}$ & $\begin{array}{c}0.111 \\
(0.033)^{* * *}\end{array}$ & $\begin{array}{c}0.108 \\
(0.033)^{* * *}\end{array}$ & $\begin{array}{c}0.106 \\
(0.033)^{* * *}\end{array}$ & 4.017 \\
\hline$z_{i} Q_{c} h_{i}$ & $\begin{array}{l}-0.044 \\
(0.032)\end{array}$ & $\begin{array}{l}-0.045 \\
(0.032)\end{array}$ & $\begin{array}{l}-0.048 \\
(0.032)\end{array}$ & -6.330 \\
\hline$Q_{c} k_{i}$ & $\begin{array}{c}0.217 \\
(0.039)^{* * *}\end{array}$ & $\begin{array}{c}0.144 \\
(0.046)^{* * *}\end{array}$ & $\begin{array}{c}0.138 \\
(0.047)^{* * *}\end{array}$ & 1.442 \\
\hline$Q_{c} h_{i}$ & $\begin{array}{c}0.118 \\
(0.030)^{* * *}\end{array}$ & $\begin{array}{c}0.129 \\
(0.032)^{* * *}\end{array}$ & $\begin{array}{c}0.131 \\
(0.032)^{* * *}\end{array}$ & 4.938 \\
\hline \multicolumn{5}{|l|}{ Additional factor endowment controls: } \\
\hline$z_{i} \ln \left(K_{c}\right) v i_{i}$ & & $\begin{array}{l}-0.041 \\
(0.072)\end{array}$ & $\begin{array}{l}-0.066 \\
(0.071)\end{array}$ & -0.054 \\
\hline$z_{i} \ln \left(H_{c}\right) v i_{i}$ & & $\begin{array}{l}0.027 \\
(0.018)\end{array}$ & $\begin{array}{l}0.024 \\
(0.018)\end{array}$ & 0.050 \\
\hline$z_{i} \ln \left(K_{c}\right)$ & & $\begin{array}{c}0.206 \\
(0.107)^{*}\end{array}$ & $\begin{array}{c}0.143 \\
(0.106)\end{array}$ & 0.416 \\
\hline$z_{i} \ln \left(H_{c}\right)$ & & $\begin{array}{l}-0.018 \\
(0.022)\end{array}$ & $\begin{array}{l}-0.019 \\
(0.021)\end{array}$ & -0.141 \\
\hline $\ln \left(K_{c}\right) v i_{i}$ & & $\begin{array}{c}-0.118 \\
(0.069)^{*}\end{array}$ & $\begin{array}{c}-0.166 \\
(0.071)^{* *}\end{array}$ & -0.035 \\
\hline $\ln \left(H_{c}\right) v i_{i}$ & & $\begin{array}{c}0.023 \\
(0.021)\end{array}$ & $\begin{array}{c}0.023 \\
(0.022)\end{array}$ & 0.013 \\
\hline VI-credit triple interaction: $z_{i} \ln \left(C R_{c}\right) v i_{i}$ & & & $\begin{array}{c}0.033 \\
(0.020)\end{array}$ & 0.096 \\
\hline Contract-intensity $\times$ Log credit: $z_{i} \ln \left(C R_{c}\right)$ & & & $\begin{array}{c}0.089 \\
(0.021)^{* * *}\end{array}$ & 0.938 \\
\hline Log credit/GDP $\times$ VI: $\ln \left(C R_{c}\right) v i_{i}$ & & & $\begin{array}{c}0.065 \\
(0.020)^{* * *}\end{array}$ & 0.051 \\
\hline Observations & 9838 & 9838 & 9762 & 9762 \\
\hline$R^{2}$ & 0.758 & 0.759 & 0.759 & 0.759 \\
\hline
\end{tabular}

Notes: This table presents estimates of equation (1). The dependent variable is $T_{c i}$, the log of country $c$ exports of industry $i$. Standardized beta coefficients are reported in columns 1-3 with robust standard errors in brackets, clustered at the 1992 I-0 2-digit level. Non-beta coefficients are reported in column 4. Judicial quality measure: Rule of Law. All regressions include a constant term, exporter and 1997 I-O industry fixed effects. ${ }^{* * *},{ }^{* *}$ and * indicate significance at $0.01,0.05$ and 0.1 levels. 
Table 4: Additional Control Variables

\begin{tabular}{|c|c|c|c|}
\hline & \multicolumn{3}{|c|}{ Beta coefficients and standard errors } \\
\hline & (1) & $(2)$ & $(3)$ \\
\hline VI-judicial quality triple interaction: $z_{i} Q_{c} v i_{i}$ & $\begin{array}{c}-0.157 \\
(0.041)^{* * *}\end{array}$ & $\begin{array}{c}-0.191 \\
(0.054)^{* * *}\end{array}$ & $\begin{array}{c}-0.190 \\
(0.061)^{* * *}\end{array}$ \\
\hline Log income $\times$ value added. $\ln \left(Y_{c}\right) v a_{i}$ & $\begin{array}{l}-0.141 \\
(0.095)\end{array}$ & $\begin{array}{l}-0.140 \\
(0.098)\end{array}$ & $\begin{array}{c}-0.194 \\
(0.095)^{* *}\end{array}$ \\
\hline Log income $\times$ intra-industry trade: $\ln \left(Y_{c}\right) i t_{i}$ & $\begin{array}{c}0.482 \\
(0.094)^{* * *}\end{array}$ & $\begin{array}{c}0.530 \\
(0.100)^{* * *}\end{array}$ & $\begin{array}{c}0.469 \\
(0.097)^{* * *}\end{array}$ \\
\hline Log income $\times$ TFP growth: $\ln \left(Y_{c}\right) \Delta t f p_{i}$ & $\begin{array}{l}-0.097 \\
(0.081)\end{array}$ & $\begin{array}{l}-0.027 \\
(0.073)\end{array}$ & $\begin{array}{l}-0.075 \\
(0.070)\end{array}$ \\
\hline Log income $\times$ input variety: $\ln \left(Y_{c}\right)\left(1-h f_{i}\right)$ & $\begin{array}{c}0.239 \\
(0.152)\end{array}$ & $\begin{array}{c}0.205 \\
(0.142)\end{array}$ & $\begin{array}{c}0.225 \\
(0.120)^{*}\end{array}$ \\
\hline Log credit/GDP $\times$ capital: $\ln \left(C R_{c}\right) k_{i}$ & $\begin{array}{c}0.055 \\
(0.031)^{*}\end{array}$ & $\begin{array}{c}0.058 \\
(0.030)^{*}\end{array}$ & $\begin{array}{c}0.060 \\
(0.031)^{*}\end{array}$ \\
\hline$\Delta t f p_{i} \ln \left(C R_{c}\right)$ & $\begin{array}{c}0.039 \\
(0.010)^{* * *}\end{array}$ & $\begin{array}{c}0.034 \\
(0.011)^{* * *}\end{array}$ & $\begin{array}{c}0.032 \\
(0.011)^{* * *}\end{array}$ \\
\hline \multicolumn{4}{|l|}{ Log income control interactions: } \\
\hline$z_{i} \ln \left(Y_{c}\right) v i_{i}$ & & $\begin{array}{c}0.238 \\
(0.171)\end{array}$ & $\begin{array}{c}0.258 \\
(0.179)\end{array}$ \\
\hline$z_{i} \ln \left(Y_{c}\right)$ & & $\begin{array}{l}-0.087 \\
(0.269)\end{array}$ & $\begin{array}{c}-0.074 \\
(0.278)\end{array}$ \\
\hline $\ln \left(Y_{c}\right) v i_{i}$ & & $\begin{array}{c}-0.312 \\
(0.158)^{*}\end{array}$ & $\begin{array}{c}-0.322 \\
(0.163)^{*}\end{array}$ \\
\hline$z_{i} \ln \left(Y_{c}\right) k_{i}$ & & $\begin{array}{c}-0.250 \\
(0.126)^{*}\end{array}$ & $\begin{array}{c}-0.229 \\
(0.129)^{*}\end{array}$ \\
\hline$z_{i} \ln \left(Y_{c}\right) h_{i}$ & & $\begin{array}{c}-0.566 \\
(0.155)^{* * *}\end{array}$ & $\begin{array}{c}-0.533 \\
(0.151)^{* * *}\end{array}$ \\
\hline $\ln \left(Y_{c}\right) k_{i}$ & & $\begin{array}{l}-0.315 \\
(0.313)\end{array}$ & $\begin{array}{l}-0.296 \\
(0.316)\end{array}$ \\
\hline $\ln \left(Y_{c}\right) h_{i}$ & & $\begin{array}{c}0.249 \\
(0.190)\end{array}$ & $\begin{array}{c}0.205 \\
(0.190)\end{array}$ \\
\hline Judicial quality interaction $\times$ labor intensity: $z_{i} Q_{c} w_{i}$ & & & $\begin{array}{c}-0.222 \\
(0.122)^{*}\end{array}$ \\
\hline Judicial quality $\times$ labor intensity: $Q_{c} w_{i}$ & & & $\begin{array}{c}0.051 \\
(0.063)\end{array}$ \\
\hline $\begin{array}{l}\text { Observations } \\
R^{2}\end{array}$ & $\begin{array}{r}9700 \\
0.761\end{array}$ & $\begin{array}{c}9700 \\
0.762\end{array}$ & $\begin{array}{c}9448 \\
0.766\end{array}$ \\
\hline \multicolumn{4}{|c|}{$\begin{array}{l}\text { Notes: All regressions in this table include the full set of controls employed in Table 3, column (3). The } \\
\text { dependent variable is } T_{c i} \text {, the log of country } c \text { exports of industry } i \text {. Standardized beta coefficients are } \\
\text { reported with robust standard errors in brackets, clustered at the } 1992 \text { I-0 2-digit level. Judicial quality } \\
\text { measure: Rule of Law. All regressions include a constant term, exporter and } 1997 \text { I-O industry fixed } \\
\text { effects. }{ }^{* * *},{ }^{* *} \text { and }{ }^{*} \text { indicate significance at } 0.01,0.05 \text { and } 0.1 \text { levels. }\end{array}$} \\
\hline
\end{tabular}




\section{Appendix A}

Data on factor intensities of production, industry value-added and TFP growth originate from Bartelsman and Gray (1996) and are based on U.S. data. Capital intensity is the total real capital stock in industry $i$ divided by the value added in industry $i$ in the United States in 1996. Skill intensity is the ratio of non-production worker wages to total wages in industry $i$ in the United States in 1996. The share of value-added is given by total value-added of each sector divided by the total value of shipments. TFP growth is averaged over the period 1976 and 1996. Labor intensity is calculated as the ratio of total payroll to value-added.

Data on factor endowments originates from Antweiler and Trefler (2002). Physical capital is measured by the natural log of the average capital stock per worker. Human capital is measured by the natural log of the ratio of workers that completed high school to those that did not complete high school. Real GDP per capita is taken from the Penn World Tables. Financial development is the natural log of credit by banks and other financial institutions to the private sector as a share of GDP in 1997, and is taken from Beck et al. (2000). Intra industry trade and the Herfindahl index of input concentration are constructed by Nunn (2007). Intra-industry trade is the amount of intra-industry trade in each industry according to the Grubel-Lloyd index for the United States in 1997. The Herfindahl index of input concentration is constructed from the 1997 U.S. I-O Use Table. 


\section{References}

Acemoglu, D., P. Antras, and E. Helpman (2007): "Contracts and Technology Adoption," American Economic Review, 97(3), 916-943.

Acemoglu, D., S. Johnson, and T. Mitton (2009): "Determinants of Vertical Integration: Financial Development and Contracting Costs," Journal of Finance, 64(3), 1251-1290.

Alfaro, L., P. Conconi, H. Fadinger, and A. F. Newman (2011): "Trade Policy and Firm Boundaries," Harvard Business School Working Papers 10-060, Harvard Business School.

Anderson, J. E., And D. Marcouiller (2002): "Insecurity And The Pattern Of Trade: An Empirical Investigation," The Review of Economics and Statistics, $84(2), 342-352$.

Antràs, P. (2003): "Firms, Contracts, And Trade Structure," The Quarterly Journal of Economics, 118(4), 1375-1418.

(2005): "Property Rights and the International Organization of Production," American Economic Review, 95(2), 25-32.

Antràs, P., M. A. Desai And C. F. Foley (2009): "Multinational Firms, FDI Flows, and Imperfect Capital Markets," The Quarterly Journal of Economics, 124(3), 1171-1219.

Antweiler, W., And D. Trefler (2002): "Increasing Returns and All That: A View from Trade," American Economic Review, 92(1), 93-119.

Bain, J. (1956): Barriers to New Competition. Harvard University Press, Cambridge, MA.

(1959): Industrial Organization. Wiley, New York, NY.

Bartelsman, E. J., and W. Gray (1996): "The NBER Manufacturing Productivity Database," NBER Technical Working Papers 0205, National Bureau of Economic Research, Inc.

Beck, T., A. Demirguc-Kunt, and R. Levine (2000): "A new database on financial development and structure," World Bank Economic Review, 14, 597-605.

Berkowitz, D., J. Moenius, and K. Pistor (2006): "Trade, Law, and Product Complexity," The Review of Economics and Statistics, 88(2), 363-373.

Carlton, D. W. (1979): "Vertical Integration in Competitive Markets Under Uncertainty," The Journal of Industrial Economics, 27(3), pp. 189-209.

Carluccio, J., and T. Fally (2012): "Global Sourcing Under Imperfect Capital Markets," The Review of Economics and Statistics, forthcoming. 
CHOR, D. (2010): "Unpacking sources of comparative advantage: A quantitative approach," Journal of International Economics, 82(2), 152-167.

Clague, C. (1991a): "Factor proportions, relative efficiency and developing countries' trade," Journal of Development Economics, 35(2), 357-380.

(1991b): "Relative Efficiency, Self-Containment, and Comparative Costs of Less Developed Countries," Economic Development and Cultural Change, 39(3), 507-30.

CoAse, R. H. (1937): "The Nature of the Firm," Economica, 4(16), 386-405.

Costinot, A. (2009): "On the origins of comparative advantage," Journal of International Economics, 77(2), 255-264.

Cuñat, A., And M. J. Melitz (2010): "A Many-Country, Many-Good Model of Labor Market Rigidities as a Source of Comparative Advantage," Journal of the European Economic Association, 8(2-3), 434-441.

Feenstra, R. C., R. E. Lipsey, H. Deng, A. C. Ma, and H. Mo (2005): "World Trade Flows: 1962-2000," NBER Working Papers 11040, National Bureau of Economic Research, Inc.

Gibbons, R. (2005): "Four Formal(izable) Theories of the Firm?," Journal of Economic Behavior \& Organization, 58(2), 200-245.

Grossman, S. J., and O. D. Hart (1986): "The Costs and Benefits of Ownership: A Theory of Vertical and Lateral Integration," Journal of Political Economy, 94(4), 691-719.

Hart, O., And J. MoOre (1990): "Property Rights and the Nature of the Firm," Journal of Political Economy, 98(6), 1119-58.

HART, O., And J. Tirole (1990): "Vertical Integration and Market Foreclosure," Brookings Papers on Economic Activity. Microeconomics, pp. 205-286.

Joskow, P. (2005): "Vertical Integration," in Handbook of New Institutional Economics, ed. by C. Menard, and M. Shirley, pp. 319-348. Springer US.

Kaufmann, D., A. KraAy, and M. Mastruzzi (2008): "Governance matters VII : aggregate and individual governance indicators 1996-2007," Policy Research Working Paper Series 4654, The World Bank.

Lafontaine, F., and M. Slade (2007): "Vertical Integration and Firm Boundaries: The Evidence," Journal of Economic Literature, 45(3), 629-685.

Levchenko, A. A. (2007): "Institutional Quality and International Trade," Review of Economic Studies, 74(3), 791-819.

Manova, K. (2008): "Credit constraints, equity market liberalizations and international trade," Journal of International Economics, 76(1), 33-47. 
McMillan, J., and C. Woodruff (1999): "Dispute Prevention without Courts in Vietnam," Journal of Law, Economics and Organization, 15(3), 637-58.

Nunn, N. (2007): "Relationship-Specificity, Incomplete Contracts, and the Pattern of Trade," The Quarterly Journal of Economics, 122(2), 569-600.

Nunn, N., And D. Trefler (2008): "The boundaries of the multinational firm: An empirical analysis," in The Organization of Firms in a Global Economy, ed. by E. Helpman, D. Marin, and T. Verdier, chap. 4, pp. 55-83. Harvard University Press, Cambridge, MA.

(2011): "Incomplete Contracts and the Boundaries of the Multinational Firm," Discussion paper, mimeo Harvard University.

Ordover, J. A., G. Saloner, and S. C. Salop (1990): "Equilibrium Vertical Foreclosure," American Economic Review, 80(1), 127-42.

Rajan, R. G., And L. Zingales (1998): "Financial Dependence and Growth," American Economic Review, 88(3), 559-86.

Ranjan, P., And J. Y. LeE (2007): "Contract Enforcement And International Trade," Economics and Politics, 19(2), 191-218.

RAUCH, J. E. (1999): "Networks versus markets in international trade," Journal of International Economics, 48(1), 7-35.

Stigler, G. (1951): "The Division of Labor is Limited by the Extent of the Market," The Journal of Political Economy, 59(3), 185-193.

Svaleryd, H., And J. Vlachos (2005): "Financial markets, the pattern of industrial specialization and comparative advantage: Evidence from OECD countries," European Economic Review, 49(1), 113-144.

Williamson, O. E. (1971): "The Vertical Integration of Production: Market Failure Considerations," The American Economic Review, 61(2), 112-123.

(1979): "Transaction-Cost Economics: The Governance of Contractual Relations," Journal of Law and Economics, 22(2), 233-261. 